\title{
REFUGEE POLICY OF THE TURKISH REPUBLIC
}

\author{
DİLEK LATİF
}

\begin{abstract}
Turkey is at the centre of refugee movements due to historical and geographical reasons. This article analyzes distinct Ottoman and Turkish policies regarding refuges and asylum seekers. Turkey signed the 1951 Convention and its 1967 Protocol with a geographical restriction. The implications of such a limitation, Turkish experience with a number of mass influxes of refugees, current refugee flows particularly from the Middle East, the 1994 Regulations and the UNHCR's role to conduct refugee status determination and resettlement will be evaluated.
\end{abstract}

\section{KEYWORDS:}

Refugees; Mass Influxes; Turkey; Middle East; UNHCR; 1994 Regulations. 


\section{Introduction}

In general, threatened and persecuted people, who lost their countries' protection, seek refuge and asylum in another country. Refugee status often results from gross human right violations, which force individuals to leave their homelands. Traditionally, differences between the societies or sometimes within a particular society have forced people to migrate other places. Besides, factors such as being a member of a religious group other than the majority of the society was one of the earliest reasons that push people to migrate. However, it was not only the religious factors that forced people to leave their homelands. The changes of the borders after wars, coup d'etats, religious or ethnic disputes are the main reasons of the refugee movements.

Although there were refugee movements in the far past, too, the conceptualization of the refugee issue begins at the end of the $19^{\text {th }}$ Century with the strict protection of country borders. The need to control refugee movements appeared after the borders gained importance and were distinguished. When the refugee movements started to have an international character, besides various national laws, some countries agreed to create international agreements to ease the issue.

The definition of the concept of refugee constituted one of the most important tasks within the international legal work. According to the definition in the Statute of the UNHCR (United Nations High Commissioner for Refugees), to be considered as a refugee, it is necessary to have a well-founded fear of being persecuted for reasons of race, religion, nationality, membership of a particular social group or political opinion. ${ }^{1}$ One must be outside the country of his nationality and must unable or unwilling to avail himself of the protection of that country or, in case of a stateless person, of the country of his habitual residence.

The legal status of refugees is defined in two international treaties; the 1951 Convention relating to the Status of Refugees and its

${ }^{1}$ Basic Facts about the UN, New York, Department of Public Information Press, 1995, p. 224. 
1967 Protocol. However, states are still the sole authorities for the final determination of who can be admitted as an immigrant or refugee. This is due to the fact that the refugee issue is considered a matter which affects the national security. The Republic of Turkey, which inherited the Ottoman Empire's long tradition of receiving refugees, is following the same course.

Political and economic crises and inabilities, caused by internal and external conditions of the Middle East, have led to both individual and mass migrations. For historical and geographical reasons, Turkey locates at the crossroad of these human movements. ${ }^{2}$ Therefore, Turkey becomes either a country of asylum or a country of transit migration. The purpose of this paper is to examine the reasons of the refugees fleeing to Turkey especially from the Middle East and political, economic and social repercussions of this process on Turkey.

The article therefore will focus on different refugee and asylum policies of the Ottoman Empire and the Turkish Republic. Implications of the geographical limitation to the 1951 Convention, the experience of the mass influxes of refugees and current refugee flows will be analyzed. It will also assess the 1994 Regulations which aimed to take over the refugee status determination from the UNHCR and the role of the UNHCR Branch Office in Ankara for refugee status determination and resettlement.

\section{Historical Background of the Refugee Movements and Ottoman Refugee Policy}

The Ottoman Empire has been subjected to large refugee movements from different directions throughout its long history. On the one hand, this was the consequence of a general state policy towards immigration. The Ottoman government came to believe that a large population was the pre-condition for economic development and strong defense against outside enemies. ${ }^{3}$ Thus, it encouraged and supported

\footnotetext{
${ }^{2}$ Mustafa Türkeş, 'Sığınmacılar Sorunsalı ve Türkiye', Umuda Doğru-Sı̆̆ıımacı ve Göçmenlerle Dayanıșma Dergisi, Vol. 2, No.11, July 1999, p. 7.

${ }^{3}$ Kemal H. Karpat, Ottoman Population 1830-1914: Demographic and Social Characteristics, London, The University of Wisconsin Press, 1985, p. 62.
} 
immigration. The decree issued by the High Council of Tanzimat on 9 March 1857 illustrates this approach. It declared that migration into the Ottoman State was open to anyone who was willing to give his allegiance to the Sultan, to become his subject, and to respect the country's laws. It stipulated further that settlers would be protected against any infringement of their religious observances and would enjoy religious freedom like all other classes of the empire's subjects. ${ }^{4}$ Response to the decree was overwhelming and applications came from different parts of Europe.

On the other hand, the Ottoman Empire has been very sensitive and tolerant on humanitarian matters. It opened its doors to many Muslims and non-Muslims who were expelled from their homelands, without making any discrimination. One example is the arrival of large numbers of Jewish refugees escaping from the Spanish Inquisition. After the achievement of Spanish unity in 1496, large-scale oppression took place against the non-Catholic Christians, Jews and Muslims. Following the application of some Jews, the Ottoman Empire accepted and settled them in İstanbul, Edirne, Selanik and İzmir. ${ }^{5}$

The rest of the Jews around 200,000 people that remained in Spain were forced to leave the country and migrate to Portugal. As a result of the same attitude of the Portuguese King Manuel I, the Jews began to search for ways to leave that country as well. In 1497, after negotiations with Portuguese Kingdom, Ottoman Empire financed the Jewish immigration from Portugal to Asia Minor. However, the Sephardic Jews were not the only Jews to seek refugee in the Ottoman Empire. Ashkenazi Jews from Germany, France and Hungary, Italian Jews from Sicily, Otranto and Calabria also flooded into the Ottoman Empire. $^{6}$

There had been other significant movements into the Ottoman Empire. Among them are the arrival of King Charles X of Sweden, as

\footnotetext{
${ }^{4}$ Ibid., p. 62.

${ }^{5}$ Muhteşem Kaynak, The Iraqi Asylum Seekers and Turkey, Ankara, Tanmak Pub., 1992, p. 13.

${ }^{6}$ Stanford Shaw, The Jews of the Ottoman Empire and the Turkish Republic, New York, New York University Press, 1991, p. 33.
} 
well as Hungarians and Poles who revolt against the Austrians. When King Charles was defeated by the Russians, he crossed the Ottoman borders with around 2000 people in 1709, and sought asylum from the Ottoman Empire. The Ottoman Sultan Ahmet III accepted the King as a guest and ordered his expenditures to be paid by the Ottoman State. The King returned back to his country in 1714. Many Hungarians and Poles escaped to the Ottoman territories during the uprising against the Austrians. In 1849, the Hungarians under the leadership of Prince Kosuth immigrated to the Ottoman Empire. They were settled in Kütahya and all their needs were paid by the Ottoman state. Prince Kosuth left Kütahya after an agreement signed between Ottoman Empire, England and France. ${ }^{7}$

Polish political leaders and their followers who had been involved in the 1848 uprisings also migrated and settled in the Ottoman state. Some of them converted to Islam, changed their names and played important parts in the political, military and cultural life of Turkey. ${ }^{8}$ For example, Mahmut Celalettin Paşa (Constantine Boznecky), an important figure in the process of modernization, was a converted Pole and later his grandson Nazım Hikmet Ran became a very famous poet of Turkey. Another Slavic migration into Ottoman territories in the $19^{\text {th }}$ century was the Bulgarian immigration. These immigrants were Ottoman subjects who had immigrated to Russia earlier in the century and were disappointed by the Russian authorities.

The first Muslim migration into the Ottoman state started with the Crimean or Tatar immigration when Crimea was incorporated into Russia. The migration intensified after the Turco-Russian war in 1812. Forcible eviction of Crimean Muslims became Russian state policy from 1856 on, and huge numbers flooded into the Ottoman territories.

The forced mass migration of the Circassions from the Caucasus into the Ottoman domain was another population movement. When the Russians occupied Circassia, persecution against the Circassians started. During the early 1850 s some Circassians migrated voluntarily, but throughout the Crimean War (1853-1856) the emigration became a mass movement. In 1859 the Russian government contacted the

\footnotetext{
${ }^{7}$ Kaynak, The Iraqi Asylum Seekers, p. 14.

${ }^{8}$ Karpat, Ottoman Population, p. 64.
} 
Turkish authorities about accepting the Circassians. The Ottoman government debated the issue and decided that it could not refuse hospitality to the Circassians who wanted to settle in the Ottoman lands in order to escape the pressure of Russian troops. ${ }^{9}$

Besides Crimean and Circassian refugees, the descendants of Turks who had settled in various parts of the Balkans for centuries, returned to Anatolia in large numbers as the Ottoman rule ended in those former provinces. Large numbers of people continued to flee from Balkans even after the collapse of the Ottoman Empire and the establishment of the Turkish Republic.

\section{Turkish Refugee Policy and Practice}

This long tradition of receiving refugees has been continued in the Turkish Republic. The collapse of the Ottoman Empire at the end of the First World War left behind many Turkish ethnic communities in various parts of the Balkans. They had been the first extensive source of refugee movements to Turkey. Large number of these people mostly from Greece, Bulgaria, Romania and former Yugoslavia fled to Turkey for political, religious and ethnic reasons.

The first refugee movement that Turkish authorities had to deal with was the painful population exchange between Greece and Turkey in 1922. The early 1920s experienced a massive movement of Muslims from Greece to Turkey and Orthodox Christians to Greece. Until the Second World War, the Turkish Republic continued to receive large numbers of refugees from former Ottoman territories. Together with the migration that took place during the Second World War, more than 800,000 people came to Turkey between 1923 and 1945.10

Apart from the Turkish and Muslim communities of the Balkans, German and Austrian refugees escaping from Nazism took refugee in Turkey in 1930s. Around 800 refugees including university professors, scientists, artists and philosophers, sought asylum in

\footnotetext{
${ }^{9}$ Tbid., p.67.

${ }^{10}$ Kemal Kiriş̧̧i, 'Post Second World War Immigration from Balkan Countries to Turkey', New Perspectives on Turkey, Vol. 12, Spring 1995, p. 65.
} 
Turkey between 1933 and 1945. Migration from the Balkans to Turkey continued also after the Second World War. During the early 1950s there was a mass influx from Bulgaria to Turkey. A second wave of Bulgarian immigration took place in 1989 due to the Bulgarian government policies towards Turks, such as forced resettlements, mass arrests, and a ban on the use of their native language, traditional names, music and customs. The Turkish government initially established reception camps for the Bulgarian Turks. However, they were free to travel, to settle and work wherever they wanted. In less than 2 years, many of the 240,000 who remained became Turkish citizens.

Another large movement of refuges from Balkans to Turkey came from Yugoslavia in 1950s. The establishment of Communist regime at the end of the Second World War in Yugoslavia was not welcomed by the Turks and Muslims living there. Bosnian and Kosovo Muslims (Albanians) were engaged in pro-Axis guerrilla movements during the Second World War and were consequently suppressed by the Tito government. The Yugoslavian migration took place mainly between the years of 1946-1970 and 182,505 people moved to Turkey. ${ }^{11}$

After the situation in Yugoslavia began to improve, both economically and politically, the migration to Turkey slowed down. Subsequently, the war in former Yugoslavia in 1992 brought about another refugee influx; approximately 20,000 Bosnians came to Turkey. The most recent refugee influx from Balkans was in 1999 when 8,300 refugees from Kosovo came to Turkey after the outbreak of Kosovo crisis. ${ }^{12}$

As all these various refugee movements demonstrate, Turkey followed the Ottoman Empire's long tradition of accepting immigrants and refugees. However, Turkish refugee policy had been much more restricted than its predecessor, which had developed a generous tradition of granting protection to different refugee groups fleeing

\footnotetext{
${ }^{11}$ Kemal Kirişçi, 'Refugees and Turkey since 1945', Boğaziçi Research Papers, ISS/POLS 94-3, İtanbul, Boğaziçi University, 1994, p. 20.

${ }^{12}$ The State of the World's Refugees, Fifty Years of Humanitarian Action, UNHCR 2000, New York, Oxford University Press, 2000, p. 239.
} 
persecution. Although Turkey is one of the drafters and original signatories of the 1951 Convention, she did not remove its reservation attached to the 1967 Protocol, which means that Turkey excludes nonEuropeans from recognition as refugees.

Turkey is an interesting example for the evaluation of the relationship between a nation state and an international refugee regime. First of all, Turkey is both a refugee producing and refugee accepting country. It is a country of mass influxes. Although, the Geneva Convention is not clear on the right to asylum en masse, Turkey had to deal with mass influxes from neighbouring countries. Turkey is a transit country for asylum seekers as well. These refugees are mainly from Iran and Iraq, but Turkey does not accept them as conventional refugees. Therefore, these asylum seekers can only achieve temporary settlement in Turkey.

Turkey is one of the countries among the signatories of the Convention in keeping a geographical limitation, along with Malta. Albeit Turkey has ratified the 1951 Convention with geographical restriction, she required the office of the UNHCR in Ankara to conduct refugee status determination of non-European asylum seekers. The UNHCR is responsible for refugee status determination and finding solutions for non-European asylum seekers. Each of these cases would be examined separately.

\section{Mass Influxes from the Middle East}

Mass influx is defined as the arrival of thousands of asylum seekers to the country within a very short period of time, usually measured in terms of days rather than weeks. ${ }^{13}$ An important characteristic of such mass influxes of refugees fleeing Turkey is that they often occurred outside the control of Turkish authorities.

Since 1945, Turkey has experienced a number of mass influxes of refugees. However, recently it has been subject to mass influxes from the Middle East. One of the most significant in size was that of Iranians fleeing the new regime in Iran after 1979. Turkey adopted a

${ }^{13}$ Kirişçi, Refugees and Turkey, p. 28. 
policy, which enabled Iranians to enter the country without a visa, and they were permitted to stay in the country temporarily. ${ }^{14}$ There are no official statistics but a member of the Turkish Parliament put the total of Iranians that benefited from this arrangement between 1980 and 1991 at 1.5 million. ${ }^{15}$ Among the Iranians, there were many Bahai's, Jews and Kurds, but the majority were opponents of the new regime or former supporters of the Shah.

Although Turkey demonstrated flexibility for their entrance, it was reluctant to satisfy internationally accepted humanitarian norms because it was eager not to offend Iran by accepting large numbers of Iranians. ${ }^{16} \mathrm{Hence}$, the overwhelming majority was encouraged to move to third countries while only a few were able to obtain residence permits to stay in Turkey.

Turkey experienced three major flows of refugees from Iraq. The first one occurred in 1988, after the war between Iraq and Iran ended. The second one took place during the Gulf crises where foreign workers and their families began to escape from Iraq. The last and the largest mass flight of refugees towards Turkey occurred soon after Iraq was forced out of Kuwait and agreed to a cease-fire in March 1991.

\section{Iraqi Kurdish Peshmergas}

Turkey experienced the first mass influx of refugees from Iraq in 1988. It took place after the attack of Iraqi forces on the civilians after the Iran-Iraq War, in August 1988. During the Iran-Iraq war, Kurds had succeeded in establishing control in certain parts of Northern Iraq. As the war turned to the disadvantage of Iraq, Kurdish peshmergas, with the support of the Iranian military began to expand their area of control southward along the Iranian border and captured the town of Halabja in March 1988. ${ }^{17}$ The reaction of the Iraqi military to the loss

${ }^{14}$ Kemal Kirişçi, 'Disaggregating Turkish Citizenship and Immigration Practices', Middle Eastern Studies, Vol. 36, No. 3, July 2000.

${ }^{15}$ Cumhuriyet, 15 February 1993.

${ }^{16}$ Elif Özmenek, 'Statelessness and Refugees as a Global Problem; Turkish Refugee Policies', Unpublished MA Thesis, Ankara, Bilkent University, 1998, p. 52.

${ }^{17}$ Kirișçi, Refugees and Turkey, p. 32. 
of this town was very violent. Iraqi forces that aimed to take the revenge attacked Halabja with chemical weapons on 17 March 1988 by air. Around 5.000 people mostly women and children died, many Kurdish villages were destroyed and at least one million Kurds were displaced.

After the Halabja massacre, the eight-year war between Iran and Iraq ended. However, Iraq had not forgotten the betrayal of the Kurds, and soon after the cease-fire attacked to the North again. With the fear of a repetition of Halabja, thousands of people left their homes. They wanted to pass the border across Turkey to save their lives. Almost 60.000 Iraqi Kurds crossed the border and sought asylum in Turkey. ${ }^{18}$ The initial reaction of the Turkish Minister of Defence was opposed to the idea of granting asylum to the refugees. However, the next day the Turkish Prime Minister announced that the humanitarian dimension of the problem necessitated the opening of the borders.

Since Turkey does not accept refugees from the Middle East, some officials believed that under international law Turkey did not have any obligations to these refugees. They preferred either to repatriate or resettle them. They avoided giving an impression that a refugee status was being extended to the peshmergas, too. Therefore, instead of the term "refugee", they preferred to use "temporary guests", "asylum seekers", or "peshmergas". This mass influx coincided with a period when the activities of the PKK (separatist Kurdish terrorist group in Turkey) were on the rise. That's why Turkey was trying to be extra careful in dealing with these refugees.

From 1988 to 1991, Europe was reluctant to accept Kurdish refugees from the camps set up in the east of Turkey near the border with Iraq. The refugee camps were in Diyarbakır-Yenikent, MardinKızıltepe and Muş-Yenikent. While Turkey was complaining about a lack of international burden sharing, human rights groups criticized Turkey for failing to recognize them as refugees and to provide full protection under 1951 Convention. ${ }^{19}$ There were also criticism of the amount and quality of the housing facilities, and harassment of the refugees by the Turkish police.

\footnotetext{
${ }^{18}$ UNHCR Country Profiles, p.1.

${ }^{19}$ Kirișçi, Refugees and Turkey, p. 50.
} 
The argument between the Turkish authorities and the West over the treatment of these refugees continued from 1988 to 1991. The declaration of a safe haven above the $36^{\text {th }}$ parallel in Northern Iraq accompanied with the activities of Operation Provide Comfort and the UNHCR's program to assist the reconstruction of Kurdish communities in the area created an environment conductive to voluntary repatriation. At the end of 1991 there were just under 19.500 refugees left in Turkey. ${ }^{20}$

\section{Refugee Flows during the Gulf War (August 1990-April 1991)}

The second refugee movement from Iraq to Turkey followed the Iraqi occupation of Kuwait. Iraq's invasion of Kuwait created a great insecurity especially among the foreigners living in this country. This precipitated large waves of panic-stricken people to flee towards Iraq's borders with the neighbouring countries..$^{21}$ Most of these people were nationals of third world countries (foreign employees, technicians, workers and their families) who did not have the means to get back to their countries. These people were not refugees in the traditional sense because they did not fear persecution in their own countries. However, given the situation in Iraq at the time, they feared for their lives and were left with no choice other then fleeing.

It was not only Kurds and foreign nationals that fled Iraq during this period. Iraqi soldiers and civilians who were tired and frightened from the war also escaped. Their situation got worse with the beginning of hostilities between Iraq and the Allied forces. This resulted in 7,489 Iraqi citizens seeking asylum in Turkey between 2 August 1990 and 2 April 1991. This figure included approximately 1,800 Iraqi military personnel, too. ${ }^{22}$ In accordance with the Geneva Convention, the Iraqi military personnel were interned by the Turkish

${ }^{20}$ US Department of State Dispatch, April 22, 1991, Vol. 2, No.16, p. 274.

${ }^{21}$ Kemal Kirişçi, 'Refuge Movements and Turkey in the Post Second World War Era', Boğaziçi University Research Papers, ISS/POLS 95-01, İstanbul, Boğaziçi University, 1995, p. 35.

${ }^{22}$ Ibid., pp. 35-36. 
military and later moved to civilian camps. The asylum seekers were taken to temporary shelters in Hakkari, Şırnak, Van and Mardin. Later, they were settled in Turkish Coal Enterprises' plants in Kangal-Sivas, the Government Guest House in Tatvan and the Agriculture School Hoster and lands in Kayseri-Kuşcu. ${ }^{23}$

\section{Refugees from Northern Iraq after the Gulf War}

After the "Desert Storm" operation against Iraq, which began on 17 January 1991, the Iraqi army was defeated and accepted the UN Security Council Resolutions on 27 February 1991. During the days that followed the cease-fire there was chaos in Iraq. The Shiite in the south and the Kurds in the north with the assistance of the foreign countries rebelled to overthrow the Saddam regime. The Kurds took many cities in the north, and the Kurdish uprising seemed to be successful until the Iraqi military turned all its might against the Kurds after having crushed the Shiite rebellion in the south. Following the negative developments, northern Iraqi Kurds fled to Turkey and Iran in panic.

The Turkish National Security Council met on amidst reports that the number of refugees at the Turkish border had already passed well beyond 200,000. As a senior Foreign Ministry official put it "Iraqi refugees (were) forcibly directed toward the Turkish border and that constituted a threat to our security." 24 This time, Turkish National Security Council decided that a flow of Kurds into Turkey constituted a threat to national security. Due to this concern Turkey closed its borders with Iraq and announced that it would consider military intervention if necessary to prevent the refugee flow, unless the United Nations Security Council acted on the issue. A letter was immediately sent to Security Council calling for a meeting and noting that a situation threatening to peace and security had emerged. ${ }^{25}$

Turkish Minister of State, Kamran İnan, stated that "the world did not help us to house and feed the refugees. At the outset of the

\footnotetext{
${ }^{23}$ Kaynak, The Iraqi Asylum Seekers, p. 46.

${ }^{24}$ Turkish Daily News, 6/7 April 1991.

${ }^{25}$ United Nations Security Council Document S/22435, 3 April 1991.
} 
1991 crises, the Turkish government decided not to repeat what they saw as their mistake in $1988^{\prime \prime}{ }^{26} \mathrm{He}$ announced that border would be closed. The military had been instructed to keep the refugees out of Turkey by all means, short of firing at them. However, the military failed to implement the decision and a growing number of refugees continued to pour into Turkey. The fact that the area along the Iraqi frontier is "inhabited by a population that through ethnic and family ties was strongly sympathetic to the plight of the refugees" created a domestic pressure on the government to change its policy. ${ }^{27}$

Therefore, the ethnic and family affiliation between refugees and the Turkish population around the border areas, accompanied with the international pressures, created flexibility in the policies of the Turkish government. ${ }^{28}$ After several meetings and negotiations between the UN Coalition and Turkish officials, a resolution was adopted by the Security Council. At around the same time President Bush announced that the United States would give support to a NATO ally that had proved its loyalty during the Gulf War.

As the tragedy of this refugee exodus unfolded on television screens, Turgut Özal, the President of Turkey at the time started to advocate the idea of creating a "safe zone". 29 Adopting a pragmatic approach, he argued that it was necessary for the asylum seekers to be brought down from the mountaintops to the Iraqi side of the border. ${ }^{30}$ He suggested that a security zone should be created in Iraqi territory under international guarantee and the asylum seekers be kept there.

The US President George Bush heeded Özal's calls by not only ordering US military air-drops to reach the mountaintops, but also dispatching Secretary of State James Baker to Turkey. In the meantime, the idea for a safe zone was taken by the British Prime Minister John Major to a European Community meeting in Brussels, specially convened to discuss the crisis. Major proposed an "enclave"

\footnotetext{
${ }^{26}$ Milliyet, 4 April 1991.

${ }^{27}$ Kirişçi, Refuge Movements and Turkey in the Past, p. 37.

${ }^{28}$ Baskın Oran, Kalkık Horoz; Çekiç Güç ve Kürt Devleti, Ankara, Bilgi Yayınevi, 1996, p. 53.

${ }^{29}$ Oran, Kalksk Horoz, p. 56.

${ }^{30}$ Ibid., p. 57.
} 
(later changed to a "safe haven") large enough to ensure the return of the refugees to their villages and towns from where they had been uprooted. ${ }^{31}$ The European Community's idea of a safe haven accompanied with Baker's report led President Bush to announce his policy in which he warned Iraq not to operate any aircraft or engage in any military operation above the $36^{\text {th }}$ parallel.

After this development, asylum seekers settled in the security zone with means supplied by Turkey and other states. ${ }^{32}$ The 460,000 refugees were first brought down from the mountains to approximately 20 transit camps along the Turkish-Iraqi frontier. The repatriation of the refugees to northern Iraq was completed at an unusually fast speed. Within five weeks, 95 per cent of Dohuk's more than 400,000 former residents had returned, as had another 60,000 persons who lived beyond Iraqi government controlled territory, but who were unwilling to proceed there. ${ }^{33}$ By early June the last of the border camps was closed down and the remaining 13,000 were moved to the camp in Silopi.

The Turkish government was much more successful in the case of the 1991 influx than the one in 1988 in terms of repatriation. It mobilized the international community for an unusually fast repatriation of the refugees, which involved the creation of safe haven in northern Iraq at the expense of the Iraqi territorial integrity. ${ }^{34}$ The Turkish government's concern that the PKK could infiltrate into Turkey from northern Iraq and arrival of large number of refugees could aggravate the Kurdish problem in Turkey created a motivation as well.

\section{Current Refugee flow from Middle East}

The majority of the refugees in the Middle East have been forced to abandon their livelihoods, their lives turned upside-down by forces

\footnotetext{
${ }^{31}$ Kirişçi, Refugees and Turkey, p. 38.

${ }^{32}$ Kaynak, The Iraqi Asylum Seekers, p. 29.

${ }^{33}$ UNHCR Report on Northern Iraq, April 1991- May 1992, Genova, United Nations High Commissioner for Refugees, 1992, p. 5.

${ }^{34}$ Kirişçi, Disaggregating Turkish Citizenship, p. 12.
} 
beyond their control. ${ }^{35}$ It was not until the 1980 s that Turkey became a country of asylum for a growing number of people from the Midddle East. The majority of these asylum seekers have come mostly from Iran, and followed by Iraq. There has also been smaller number of asylum seekers from other Middle Eastern countries such as Egypt, Jordan, Syria and Tunisia.

Two particular forces shape current flows into Turkey. First, political turmoil in neighboring areas which have pushed migrants into the country of hope of a safer life and protection from persecution. Second, Turkey's geographic location between East and West, North and South which has made the country a transit zone for many migrants in search of a better life in western and northern countries.

\section{Turkey as a Transit Country}

Transit migrants are the people who come to a country of destination with the intention of passing into another country. Thousands of migrants, with the intention of temporary stay, have come to Turkey to find their way to the developed countries in the West and North. The reasons of Turkey being preferred as a transit country especially in access to Europe are various. Turkey is located within the same geography and under common borders which is the most significant and definite factor. It is the only gate opening to Europe with its function of a bridge between Asia and Europe. That is to say Turkey is between the countries whose living conditions are not good and countries with high living standard.

The other consideration is the suitability of illegal entries due to mountainous and difficult to control geographical formation, in addition to the long land borders with the neighbours. Turkey has land and sea borders in common with Greece and Bulgaria, which are used as transit countries after Turkey, too. The Aegean and Mediterranean coasts have long and suitable natural characteristics that enable illegal entries.

${ }^{35}$ Amnesty International, News Release-MDE, 3 September 1997. 
Besides, the people of the region living in the east have tribe and kin relations with the people over the borders that enable them to cooperate easily. Additionally, people living in the regions in which illegal entries and exits occur regard human smuggling, as a means of living. Some of the citizens living at the coast line, for example, consider human smuggling as a source of income particularly during winter months when tourism activities decrease. ${ }^{36}$ PKK terror organization, which was active in the region, accorded passage to these people in exchange for material and political benefit.

The most important factors that bring the refugees to Turkey are armed conflict, ethnic intolerance, religious fundamentalism, and political tension in their home countries. ${ }^{37}$ Economic motives are of primary significance as well. Most of the transients are entering Turkey without any valid documents such as a passport or a refugee document. Almost one third of the refugees are planning to use traffickers to help them pass to their final destinations. ${ }^{38}$

The process of transit migration in Turkey is relatively a new phenomenon. However, it is likely that it would increasingly continue in the coming years. Therefore, Turkey needs to build the necessary infrastructure and institutions to deal with the transit migration flows.

\section{Refugees from Iran}

The largest group of the current refugees has been Iranians. As Iranian citizens do not need a visa they can easily enter Turkey, seek refuge in Turkey or use Turkey as a step to reach Western countries. Turkish authorities do not recognize Iranian citizens as asylum seekers under the terms of the Geneva Convention. However, they can stay on as tourists while a small proportion of them took their claims for

\footnotetext{
${ }^{36}$ 'Approach to Refugee Law in Turkish Legislation, Illegal Immigration and Human Smuggling', Report of the Ministry of Internal Affairs General Directorate of Security, Presidency of Foreigners Border Refugee Department, 1999, p.11.

${ }^{37}$ Ahmet Içduygu, 'Transit Migrants in Turkey', Boğaziçi Journal, Vol. 10, No.1-2, 1996, p. 127.

${ }^{38}$ Ibid., p. 133.
} 
asylum to the UNHCR. Those recognized by the UNHCR have then been resettled in third countries.

There are mainly three groups of refugees from Iran. The first group consists of members of the Iranian elite who were closely associated with the Shah before he was deposed. Many belonging to this group fled Iran via Turkey. The second group is comprised of those who were originally supportive of the revolution in Iran but later became disenchanted by Ayatollah Khomeini's repressive policies. Among them were supporters of opposition groups such as the Mujahedin-e-Khalq and the Tudeh Party. ${ }^{39}$ Those in this group continue to seek refuge in Turkey.

The third group involves the Kurds. The Kurdish population in Iran lives mainly along the borders with Iraq and Turkey. The 1979 Islamic Revolution was seen by Kurdish activists as an opportunity to gain autonomy. The KDPI (Kurdish Democratic Party of Iran) managed to take over temporarily much of the area from Mahabad to Sanandaj. However, Kurdish fighters, along with the sympathisers were sentenced to death and executed by the Revolutionary Guards. After the end of the Iran-Iraq war, military pressure on the Kurdish opposition was increased. Many Kurdish villages were destroyed and depopulated while Kurdish political leaders have been the targets of assassinations. ${ }^{40}$ As the armed conflict between the Iranian security forces and the Iranian Kurdish guerrilla groups continued, it led to a steady flow of Kurdish refugees into Turkey.

Apart from the three main groups, we can add one other minor group of refugees from Iran. These are members of various religious minorities, including Armenians, Assyrians and Jews, compelled to flee Iran to third countries via Turkey. Although, the constitution of the Islamic regime in Iran includes provisions for the protection of the rights of "people of the Book", many members of non-Muslim religious communities have experienced persecution, which led them to flee to Western countries and Israel via Turkey. ${ }^{41}$ The largest number of such

\footnotetext{
${ }^{39}$ Background Paper on Refugees and Asylum Seekers from Iran: [http://www.unhcr.ch/refworld/cdr], September 1998, p. 2.

${ }^{40}$ Tbid., p. 23.

${ }^{41}$ Kirișçi, Refugees and Turkey, p. 15.
} 
refugees was from the Jewish community after Ayatollah Khomeini came to power.

However, the religious minority, which had to suffer most in Iran, is the Baha'is. The Baha'i faith, with about 350,000 believers, was founded in Iran in the 1840 s and is not protected by the Iranian Constitution. According to the UN Special Representative, the human rights of members of the Baha'i community continue to be violated, through "extrajudicial executions, arbitrary detentions, refusal of entry to universities, confiscation of property, and dismissal from employment." ${ }^{\prime 2}$ Since 1979, many members of this community have been compelled to leave Iran illegally, often to go to Turkey or to the West through Turkey.

\section{Refugees from Iraq}

The second largest group of refugees from the Middle East is coming from Iraq. Iraq has been an important source country of refugees and asylum-seekers over a number of years. Nearly 20 million Iraqis continue to suffer under the combined impact of a repressive government policies and a eleventh consecutive year of economic sanctions. ${ }^{43}$ There is an absolute domination of the Saddam Hussein's government on Iraq as the President, Chief of Revolution Committee Council and the General Secretary of Baas Party. ${ }^{44}$ The government practices arbitrary arrests, torture, lack of due process, and the expanded use of death penalty on a population suffering from critical shortages of food and medicine, high employement and hyper-inflation.

Specific ethnic and religious communities in Iraq such as Kurds, Turkomans, Shi'a Moslems and Christians are under a great pressure. Since Kurds constitute the largest ethnic minority, the government tries to keep them loyal by force. In the case of Turkomans, their national identity, civil and political rights are not recognized by the Constitution of Iraq. Thus, their existence is ignored. The use of their language,

\footnotetext{
42UN General Assembly, A/52/472, 15 October 1997.

${ }^{43}$ Background Paper on Iraqi Refugees and Asylum Seekers: [http://www.unhcr.ch7refworld/country], September 1996, p. 4.

44، Approach to Refugee Law in Turkish Legislation', p. 8.
} 
cultural and property rights are restricted. The government has been forcing them to immigrate, too.

Among the religious communities, the Shi'as comprise an estimated $55 \%$ of the total population. The Shia opposition movement in Iraq was radicalized by the Iranian Revolution. Inspired by Iran, the Shi'as undertook a large-scale rebellion after Iraq's defeat in the Gulf War. The central government crushed the uprising and the repression of the Shi'a majority of Iraq has continued since then. Christians, as another religious group, have been under great pressure since the Gulf War because it is percieved that they have closer ties with the West. ${ }^{45}$ As a consequence, tens of thousands of Christians have tried to leave the country.

The fragile economic and security situation in Northern Iraq is another reason of the refugee flows from Iraq. The Kurds living in Northern Iraq are under a double embargo, one imposed on Iraq by the United Nations and one imposed by Baghdad. They are almost completely dependent on Western aid. Apart from their economical problems, they were also involved in intra-Kurdish fighting. Fighting that began as minor disputes, eventually escalated into a renewal of what was essentially a dispute between Mas'ud Barzani's Kurdistan Democratic Party (KDP) and Jalal Talabani's Patriotic Union of Kurdistan (PUK) for ultimate control over the Kurdish population and territory. Due to the lack of authority, there was no security to the people in the area. Numerous Kurdish people died in the civil war between this two rival groups. Many fighters were taken prisoner by the opposition groups. Most of them were later released in prisoner exchanges but some were killed after capture. Unarmed civilians were detained on the basis of their affiliation. Many people were executed after unfair trials. Since the conditions have not changed to better in the region, people still fear persecution and continue to flee Turkey.

Another refugee group from Iraq is the former Iraqi military personnel who fought with Saddam and then came to conflict with the regime. There is a special UNHCR procedure for such people. They should not have committed any crime against humanity to be accepted as a refugee. Most of the deserters from the Iraqi army escape to

${ }^{45}$ Ibid., p. 23. 
Turkey as well. In Iraq, persons who are away for longer than 15 days from their military unit are considered as deserters. The Iraqi government is imposing humiliating penalties such as cutting the ears of those who do not wish to complete their military service and escape from the military service. In general, refugees from Iraq left their countries because of lack of respect in fundamental human rights and freedoms, deteriorating economic conditions due to UN embargo, heavy penalties for crimes as well as pressures applied mainly on the minorities and regime opponents by the government of Saddam.

\section{Turkey's Legal Procedures for the Refugees and Asylum Seekers}

From 1923 until the 1950s, the Turkish Republic had no specific refugee policy. She usually felt responsible for ethnic Turks or Muslims in the Balkans. However, the end of World War II, followed by the creation of the bipolar power structure and the establishment of the $\mathrm{UN}$, led to a transformation in the international refugee regime as well as Turkey's own refugee policies. ${ }^{46}$

Since the relationship between the West and Turkey became more organic in the early 1950s, Turkey accepted the 1951 Geneva Convention. However, Turkey is one of the few countries, which, having signed the 1951 Refugee Convention and its 1967 Protocol, maintains so-called "geographical limitations", in this case providing protection only to people from European countries. ${ }^{47}$

Like all other signatories, Turkey's acceptance of the 1951 Convention carried a geographical and time reservation. With the 1967 Protocol while almost all other signatories were removing their reservations on the refugee definition, Turkey did not remove its geographical reservation that excluded non-Europeans as refugees.

The major reason for the acceptance of 1951 Treaty with geographical limitation by Turkey was the fact that it wanted to

\footnotetext{
${ }^{46}$ Özmenek, Statelessness and Refugees, p. 39.

${ }^{47}$ UNHCR, Country Profiles-Turkey: [http://www.unhcr.ch/world/euro/turkey.htm], p. 1.
} 
eliminate the possible social, economical and political problems by means of closing its doors to Middle East and Asia where refugee movements were are experienced intensively. According to the view of Turkish officials, these areas were (and still are) politically and economically unstable and prone to refugee movements. Turkey perceived refugee movements from this region as a potential threat to its security. The belief that Turkey does not have the economic resources to extend general support was also influential.

Within this framework, refugees can be classified in three categories in terms of application: (1)Conventional Refugees, (2)NonConventional Refugees, and (3)National Refugees. Those who escape from the countries in Europe to Turkey and fulfil the conditions to acquire refugee status are considered as international refugee (conventional refugee). In practice, this is understood that refugee status and asylum would be given only to individuals escaping from communist persecution in Eastern Europe and the Soviet Union during the course of the Cold War.

Furthermore, in general Turkey granted refugee status to such asylum seekers with the understanding that recognized refugees would, eventually, be resettled in third countries. This attitude of Turkey comprised two political reasons. The first was the apparent stance of the Turkish foreign policy during the Cold War. As a supporter of the anti-communist policy it was natural to help East European refugees at that time. The second reason was that the refugees from Eastern Europe came always in small numbers and the West was ready to resettle them in a Western country. Consequently, there were no economic, political and social problems for Turkey to integrate the refugees into the society. Moreover, the fact that the costs of sheltering and resettling these refugees were often met by international agencies, such as the International Catholic Migration Commission and the UNHCR.

Non-Conventional refugees are the ones mostly coming from the Middle East. They are mainly comprised of Iranians, Kurds and Iraqis. They used to arrive in small groups until 1980s. Then, Turkey started to face with mass influxes from the Middle East. Initially Turkey was reluctant to open its borders to the refugees from the Middle East and referred to the geographical limitation in the Geneva Convention to 
justify its position. As it was discussed before, due to the emergency of the later situations, Turkey had to open its borders.

Although, Turkey does not recognize the people fleeing from the Middle East as refugees, the individuals have the right to apply for refugee status and seek resettlement through the UNHCR. Turkish authorities grant such individuals the right to reside temporarily in Turkey during the period when their cases are considered by the UNHCR. People in this group are interviewed by UNHCR for the refugee status determination. However, this working relationship is based on a strict understanding that such asylum seekers or refugees will not remain in Turkey permanently. ${ }^{48}$ The non-conventional refugees, who are recognized as refugees in need of protection, must seek resettlement in a third country since resettlement is the only durable solution for them.

\section{National Refugees}

The determining criteria for refugee status in case of national refugees are social repressiveness and a blend of cultural, historical, and religious factors. ${ }^{49}$ It is the Law on Settlement (No.2510) that governs migration into Turkey. According to this Law, only those who have Turkish ethnic descent and are of Turkish culture are entitled to migrate, settle, and receive Turkish citizenship.

By and large, Turkish-speaking communities in the Balkans, Caucasus and Asia have come within the scope of the Law. The Albanians, Bosnians and Pomaks who are not ethnically Turkish, have also benefited from the provisions of this Law. According to this criteria, Turkey accepted and assisted refugees such as Bulgarian Turks and Pomaks, Bosnian Muslims, and Turkomans from Northern Iraq. ${ }^{50}$ However, recently, there is a debate these people, who are defined as national refugees, are real refugees. They are mainly escaping from authoritarian regimes and poor economic conditions.

\footnotetext{
${ }^{48}$ Kirișçi, Refugees and Turkey, p. 6.

${ }^{49}$ Özmenek, Statelessness and Refugees, p. 44.

${ }^{50}$ Kemal Kirișçi, 'Refugee Movements and Turkey', International Migration, Vol. 29 , No. 4, 1991, p. 545.
} 
Their primary motive is to acquire Turkish citizenship. Besides, there is a growing interest in questioning the notions of Turkish national identity and the boundaries of Turkish citizenship. Consequently, with the increase in the population and unemployment in Turkey, local authorities became more reluctant to accept and settle this kind of people.

\section{Regulations}

Until 1994, there was no comprehensive Turkish legislation relating specifically to refugees and asylum seekers. However, references, which relate to these groups, could be found in various other legislation such as the Constitution of the Republic of Turkey, Settlement Law, Regulations on Settlement Exemptions, Passport Law, or Law on Belligerent Foreign Armies' Members, who Take Refuge in Turkey.

Thus, there has been a long-lasting debate about the procedures for the asylum seekers who were recognized as bone fide refugees or "people of concern" to the UNHCR, among the Turkish officials and the UNHCR. ${ }^{51}$ The problem was aggravating when the refugees recognized by the UNHCR were trying to leave Turkey for resettlement. Turkish officials were refusing to allow them to leave the country because of their illegal entrance or presence in the country.

The conflict between the UNHCR and the Turkish authorities intensified after the mass influxes of refugees to Turkey. From 1980s the non-conventional refugees started to challenge the practices of Turkish authorities in relation to refugee policies. First, they were coming in large numbers. Second, their resettlement was not guaranteed. Third, Turkey did not have any international obligation for non-conventional refugees. Since neighbouring areas in the Middle East have been highly unstable and prone to refugee movements, Turkish officials started to consider the refugee movements from this area as a potential threat to Turkey's national security. Moreover, illegal immigration to Turkey from the Middle East dramatically increased in recent years. Therefore, Turkey felt obliged to introduce

${ }^{51}$ Kirişçi, Refugees and Turkey, p. 6. 
its own refugee status determination in July 1994 and formalized it in November 1994.

The legal status of the non-European refugees in Turkey was established in the 1994 Asylum Regulation, which provide for temporary asylum to non-European refugees pending their resettlement to a third country. ${ }^{52}$ This legislation has assumed particular importance given the fact that Turkey has signed the 1951 Convention on the Statues of Refugees and its 1967 Protocol while maintaining the documents' geographical limitation.

The is named as "The Regulation on the Procedures and the Principles Related to Population Movements and Aliens Arriving in Turkey either as Individuals or in Groups Wishing to Seek Asylum either from Turkey or Requesting Residence Permission in Order to Seek Asylum from Another Country." 53 It is divided into five sections. The first section (Article 1-3) includes the purpose, contents and the definition of the terms such as refugee, asylum seeker, belligerent foreign army member and individual alien. The second section (Article 4-7) describes the procedures and principles of asylum applications. If individual foreigners enter the country illegally, they are required to apply within five days to the local Governorates, and if they enter legally, then they are required to register with the Governorates in the city where they entered the country within five days. The regulation identifies the Interior Ministry as the final decision-making body for status determination. The third (Article 8), and fourth (Article 9-25) sections of the Regulation deal with mass asylum policies. Part 5 (Article 26-33) introduces general rules concerning asylum in general. $^{54}$

Although the regulation can be considered as a major development in the refugee policy of Turkey, it created some problems and ambiguities. The commonly pointed out problem was the five days limit for filling a request for asylum with Turkish authorities. This is considered to be a very short period of time, especially for the asylum seekers who find themselves have to go back to the border provinces of

521999 Global Appeal: [http://www.unhcr.ch/fdrs/ga99/tur.99], p. 2.

${ }^{53}$ Official Gazette, 30 November 1994.

${ }^{54}$ Ibid. 
Turkey. For whatever reason, those who fail to comply with this requirement are liable to immediate deportation without any consideration of their asylum claims. ${ }^{55} \mathrm{~A}$ further complaint concerns the lack of expertise in status determination as well as translation facilities especially in eastern provinces of Turkey. ${ }^{56}$

Another point is about the time limitation of Article 28 on resettlement, which has to be done within a "reasonable" time period. This is very ambiguous and leads to subjective interpretations. A number of refoulement cases took place in which refugee status have been accepted but failed to find a country for resettlement.

According to the new regulations, the UNHCR would consider resettling refugees whose status have been approved by the Turkish authorities. After the application of the new regulations the Turkish government has been heavily criticized. There was a debate that Turkish government's new refugee processing system conflicts with basic requirements for fairness and legitimacy of the refugee status determination procedure. As a result of the pressures and complains from many international organizations such as Amnesty International and the U.S. Committee for Refugees to drop the time limitation on filling asylum claims, the five days limitation was increased to ten days in January 1999.

However, in the context of its candidacy for EU membership, Turkey issued in March 2001 a National Plan of Action for the Adoption of the European Union Acquis (NPAAA). ${ }^{57}$ This Plan includes a qualified commitment to the lifting of the geographical limitation. The document also announced the Government's intention to review its legislation and regulations on asylum, and called for intensive training of officials in refugee protection, improvement of support arrangements for refugees, and close collaboration with UNHCR and relevant NGOs.

\footnotetext{
${ }^{55}$ Refoulement of Non-European Refugees- A protection Crises, Amnesty International Report EUR 44/31/97: [http://www.amnesty.org/aisect.contacts.htm.], p. 1 


\section{UNHCR in Turkey}

As states make the final determination of who is a refugee and who is therefore entitled to temporary asylum from persecution, primary role of the UNHCR is to help states determine who should not be returned to a situation of possible persecution. In general, UNHCR has six functions in dealing with refugee problems: protection, assistance, promoting solutions, repatriation, local integration and third country resettlement. ${ }^{58}$ Its founding statute entrusts the UNHCR with two main and closely related functions to protect refugees and to promote durable solutions to their problems.

Since Turkey maintains a geographical reservation to the 1951 Convention, UNHCR in Turkey is responsible for the legal determination of refugee status and resettlement of the refugees to the third countries. It also offers counselling and provides material assistance including credit schemes, education, food, lodging and health care to asylum-seekers and refugees of various nationalities. Basically, the agency assists refugees in applying for resettlement to third countries and in seeking other durable solutions.

UNHCR Branch Office in Ankara is essentially responsible for refugee status determination and finding solutions for non-European asylum-seekers. Turkish authorities may grant temporary permit to stay for a non-European asylum seeker, but if he or she is then recognized as a refugee in need of protection, the person must seek resettlement in a third country. The UNHCR seeks solution to their problems through resettlement to third countries, since resettlement is the only durable solution for non-European refugees.

Nevertheless, the UNHCR enjoys close and regular consultation with the government of Turkey on the functioning of the asylum system, including the eligibility of individual asylum-seekers and how to ensure their protection. In 2000, the UNHCR and the Turkish government signed a three-year framework agreement on training and technical cooperation in the field of asylum. ${ }^{59}$

\footnotetext{
${ }^{58}$ The State of the World's Refugees, p. 3.

${ }^{59}$ UNHCR 2001 Global Appeal, p. 2.
} 
In practice, UNHCR's traditional activities in Turkey have mainly concerned the needs of individual asylum seekers from Iran and Iraq since they constitute 96 per cent of asylum-seekers in Turkey. Since the numbers of the Iraqi and Iranian refugees are very high, UHNHCR Branch Office in Ankara has an extremely important role in Turkey's refugee policy making.

The UNHCR helps the refugees and asylum-seekers in Turkey from Middle East by providing financial aid, food assistance for vulnerable groups, medical care, covering accommodation costs and local travel expenses, and providing legal and social counselling, pending status determination and resettlement for recognized refugees.

Access to the Turkish government's asylum procedure is a problem for the non-conventional refugees. Asylum-seekers who have entered Turkey without valid documents are required to register with the authorities in the governorate closest to their points of entry within ten days. The UNHCR is also present in border areas to monitor refugees and counsel asylum-seekers about Turkish asylum regulations.

In addition to the fact that the UNHCR has a limited budget, its partners such as the ICMC (International Catholic Migration Commission), CARITAS, the ASAM (Association of Solidarity with Asylum Seekers and Migrants), the ADP (Anatolian Development Foundation), Turkish Red Crescent Society and International Red Cross are usually insufficient to support the refugees from Middle East financially while waiting for their resettlement to a third country.

\section{Conclusion}

Turkey has been a gateway to the East and considered as a bridge between the East and the West. Owing to its geographical location Turkey has become a transit country, recieving many refugees and asylum seekers, majority of which are Iranians, Iraqis and Kurds. Similar to its predecessor, Ottoman Empire, Turkey has a long tradition of accepting immigrants and refugees. However, in contrast to the Ottoman Empire, the Turkish Republic has followed a different 
refugee policy. In respect to granting of refugee status, Turkey applies a much more restrictive policy. Hence, Turkey signed the 1951 Refugee Convention and its 1967 Protocol with geographical limitations and accepted to provide protection only to refugees from European countries.

However, instead of dealing with the refugees from Europe, Turkey had to cope with refugees mainly from the Middle East. The disorder which has been continuing for a long time in the Middle East, the regime change in Iran, the Iran-Iraq War in 1980s, the Gulf Crisis in 1991, and economic difficulties and the violation of human rights in the region led people to escape collectively or individually to more secure regions. In this context, Turkey has become a major country of asylum.

Nevertheless, the attitute of the Turkish government toward the issue is hardening. Turkish officials fear that Turkey may become a buffer zone between refugee generating areas in the world. In fact, their main concern is that this can adversely affect Turkish national security. This makes them reluctant to lift the geographical limitation on the Genova Convention.

Turkish government is also taking a stricter approach towards status determination for asylum seekers. It argues that many asylum seekers who come to Turkey are illegal economic immigrants who are trying to go to Western Europe. The traditionally generous policies towards national refugees are changing, too. The growing economic difficulties and unemployement in Turkey led to a more strict regulations for the national refugees.

After the end of Cold War, the concepts of "refugee" and "asylum-seeker" became important issues on the government's agenda. Mass influxes of refugees from the Middle East and the growing pressures on the people in the region to migrate have even pushed these issues to the top of the Turkish government's agenda. Consequently, Turkish government adopted the 1994 Regulations to control and regulate asylum from outside Europe.

Although Turkey's tradition of asylum and refugee policies has changed over the years, it continues to grant refugee status to 
individuals or to large groups of people fleeing persecution. However, Turkey's policy towards "non-conventional" refugees depends strongly on the commitment of the international community to share the financial burden and assist in efforts for repatriation. In case Turkey lifts the geographical limitation to adopt refugee policy to European Union's asylum policy, this would be a step further for better implementation of 1951 Convention. It might also result in tightening the control of the borders to deter illegal immigration flows due to the existing immigration policies of the Union. 